УДК 598.2:591.54:502.7 (571.62)

\title{
НОВЫЕ СВЕДЕНИЯ О РЕДКИХ ВИДАХ ПТИЦ ХАБАРОВСКОГО КРАЯ
}

\author{
В. В. Пронкевич ${ }^{1,2}$ \\ ${ }^{I}$ ФББУН Институт водных и экологических проблем ДВО РАН, \\ ${ }^{2}$ ФГБУ «Заповедное Приамурье», г. Хабаровск \\ E-mail: vp_tringa@mail.ru
}

\begin{abstract}
В основу статьи положены наблюдения автора, проведенные в 2016-2018 гг. на территории Хабаровского края. Впервые для региона отмечено размножение обыкновенного скворца и галстучника. Получены документальные подтверждения размножения сухоноса в Ульбанском заливе Охотского моря. Сообщается о новых залетах в регион египетской цапли и колпицы. Приводятся новые данные по состоянию численности мандаринки и чешуйчатого крохаля на pp. Хор, Анюй и о некоторых деталях биологии исчезающего вида мировой орнитофауны - охотского улита в зал. Счастья Охотского моря.
\end{abstract}

Ключевые слова: распространение, численность, редкие виды птиц, Хабаровский край.

DOI: 10.34078/1814-0998-2019-2-89-98

\section{ВВЕДЕНИЕ}

Территория Хабаровского края в орнитологическом отношении исследована весьма неравномерно, а некоторые районы, прежде всего северные, вследствие их труднодоступности, можно отнести к крайне слабоизученным. Наиболее полно исследованы южная и центральная части региона (Яхонтов, 1963; Росляков, 1989; Воронов, Пронкевич, 1991; Бабенко, 2000; Воронов, Поярков, 2000; Тиунов, 2002; Пронкевич и др., 2011; Пронкевич, Мороков, 2012; Розенфельд и др., 2014).

В 2016-2018 гг. в рамках выполнения грантовых проектов «Ключевые орнитологические территории Юго-Западного Приохотья: изучение и сохранение»; «Эколого-экономическое обоснование организации водно-болотного угодья "Морские заливы Николая, Ульбанский и Константина"» в Тугуро-Чумиканском муниципальном районе Хабаровского края; «Ключевые орнитологические территории Юго-Западного Приохотья: изучение и сохранение (Этап 2. Caхалинский залив и Амурский лиман)»; «Nordmann's Greenshank and Redshank Breeding Ecology Study in the Bay of Schast'e, Sea of Okhotsk, Russia» у нас появилась возможность обследовать ряд морских заливов в Юго-Западном Приохотье и уже известные ключевые для птиц территории внутри материка (проект «Scalysided Merganser Survey in Khabarovsk Region, Russia»).

(C) Пронкевич В. В., 2019
Основными задачами исследований были выявление ключевых для птиц местообитаний, подготовка обоснований для организации особо охраняемых природных территорий (ООПТ), выяснение деталей биологии редких видов птиц, налаживание мониторинга и выявление тенденций динамики численности птиц.

\section{МАТЕРИАЛ И МЕТОДИКА}

Материалом для данного сообщения послужили сведения, собранные автором в 20162018 гг. на территории Хабаровского края. С 9 по 19 мая 2016 г. был проведен учет мандаринки и чешуйчатого крохаля в бассейне р. Хор. Учет птиц проводили двукратно - с движущейся против течения мотолодки и при пассивном сплаве по водотокам. Были обследованы участки p. Хор (от устья р. Сооли до устья р. Матай, всего 265 км), нижние течения рр. Сукпай (53 км), Чукен (34 км), Кафэ (32 км) и Катен (56 км). Общая протяженность обследованных участков русел составила 440 км.

С 8 по 20 июля 2016 г. и с 8 по 23 августа 2016 г. с использованием мотолодок выполнено обследование зал. Николая, Ульбанский и Константина Охотского моря и впадающих в них pp. Усалгин, Большой Обкан, Ульбан, Эльго, Сыран и Эльгандё, восточного побережья зал. Тугурский от перешейка до устья р. Биранжа (1870 км).

В 2017 г. с конца апреля по конец августа проведено пять маршрутных учетов мандаринки и чешуйчатого крохаля на р. Анюй в границах национального парка «Анюйский» от устья р. Богба- 
су $\left(49.375540^{\circ}, 137.716426^{\circ}\right)$ до устья р. Манома $\left(49.324675^{\circ}, 136.610621^{\circ}\right)$ (всего 140 км).

С 23 по 26 мая 2017 г. учет мандаринки выполнен на участке основного русла р. Анюй от пункта, расположенного в 5 км по течению ниже впадения р. Яко $\left(48.739926^{\circ}, 138.086761^{\circ}\right)$ до устья р. Богбасу по течению выше территории национального парка «Анюйский». Общая протяженность учетного маршрута составила 140 км. Птиц учитывали дважды: при движении против течения по реке на лодке под мотором и по течению при пассивном сплаве.

С 21 мая по 16 июля 2018 г. проведены маршрутные учеты и наблюдения за поведением охотского улита на западном побережье зал. Счастья Охотского моря на участке от устья р. Иска до основания Петровской косы. Маршруты охватывали приморские луга, моховые болота и лиственничные леса. Общая протяженность пеших учетных маршрутов составила около 400 км.

Некоторые сведения о встречах редких видов птиц получены от бывшего сотрудника национального парка «Анюйский» В. М. Гневашева, зоолога С. В. Иванова, охотоведа А. Д. Степных.

Русские и латинские названия птиц, а также порядок перечисления видов в данной публикации приведены по сводке В. А. Нечаева и Т. В. Гамовой (2009).

\section{РЕЗУЛЬТАТЫ РАБОТ}

Египетская цапля Bubulcus ibis (L.) внесена в Красную книгу Российской Федерации (2001). На территории Хабаровского края египетская цапля в качестве редкого залетного вида регистри-

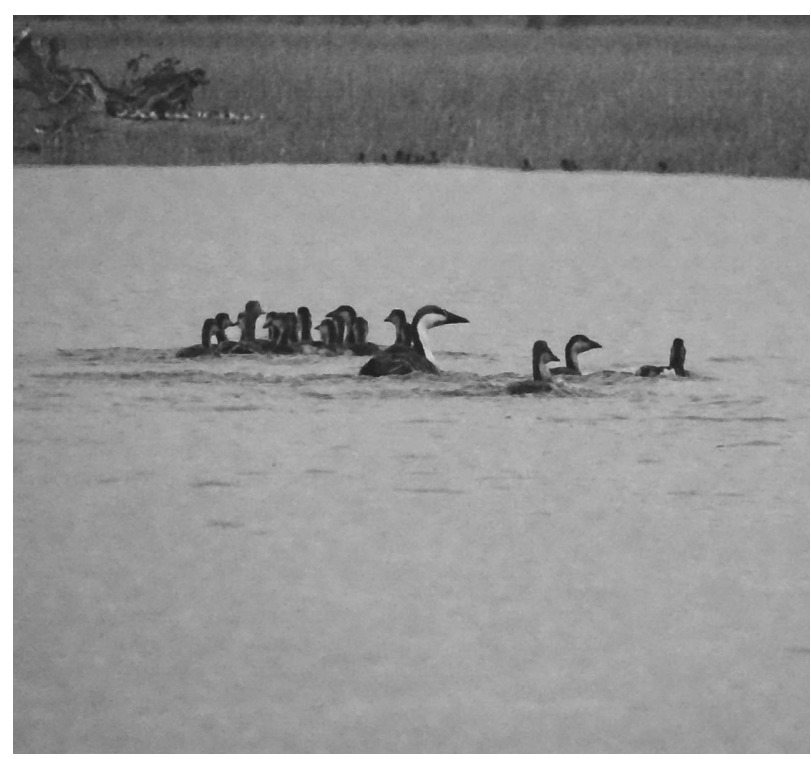

Pис. 1. Фрагмент объединенного выводка сухоноса Fig. 1. Part of the joint brood of the Swan Goose руется с 2000 г. В последующие годы частота ее встреч увеличивалась. Вид отмечен на побережье Татарского пролива у с. Гроссевичи, в пойме р. Пир и на р. Гур (Тиунов, 2002; Пронкевич и др., 2011; Пронкевич, 2013). Все встречи птиц происходили в поздневесенний период.

21 мая 2016 г. одиночная взрослая птица отмечена и сфотографирована нами на обочине автотрассы Хабаровск - Комсомольск-на-Амуре вблизи оз. Синдинское $\left(48.899277^{\circ}, 136.194892^{\circ}\right)$. Это уже четвертая встреча египетской цапли в регионе.

Колпица Platalea leucorodia L. включена в Красную книгу РФ и относится к очень редким залетным видам Хабаровского края.

По сообщению В. М. Гневашева, хорошо знающего этот вид, 5 мая 2017 г. шесть летевших колпиц встречены им на левом берегу Амура в 7 км по течению выше истока пр. Эморон $\left(49.372695^{\circ}, 136.359161^{\circ}\right) .27$ апреля 2018 г. этим же корреспондентом там же отмечены четыре летевшие колпицы.

Ранее были известны встречи колпицы на Среднеамурской низменности в бассейне оз. Болонь, на оз. Киотеми, в междуречье Обор - Сита в окрестностях с. Князе-Волконское и в окрестностях с. Малышево. В последнем пункте в мае 1965 г. был зарегистрирован единственный случай размножения вида в регионе (Росляков, 1981; Пронкевич и др., 2011; Пронкевич, 2015).

Cухонос Anser cygnoides (L.). Редкий гнездящийся вид, внесен в Красную книгу РФ (2001). В зал. Ульбанский Охотского моря скопление сухоносов, включавшее более 200 линных особей, впервые найдено нами в августе 1989 г. Шкурка добытого в заливе местным охотником сухоноса была передана в Зоологический музей МГУ (Воронов, Пронкевич, 1991). В настоящее время, несмотря на периодические случаи незаконного отстрела гусей, численность этой группировки птиц, вероятно, сохраняется на уровне 30-летней давности (Воронов, Поярков, 2000; Розенфельд и др., 2014; Пронкевич, 2016). Многочисленные сведения, полученные от рыбаков с. Тугур, указывали на размножение сухоноса в зал. Ульбанский, но гнездование вида документально не было подтверждено. 20 июля 2016 г. в 5 ч 20 мин по местному времени в нижнем течении р. Эльго $\left(53.554874^{\circ}, 137.228362^{\circ}\right)$ мы встретили и сфотографировали объединенный выводок сухоноса, состоявший из двух взрослых птиц и 25 птенцов величиной в $2 / 3$ взрослой птицы (рис. 1).

В августе 2016 г. в южной части зал. Ульбанский в общей сложности учтено 189 сухоносов - встречены три стаи летных птиц, состо- 
явшие из 164, 10 и 15 особей. В настоящее время в зал. Ульбанский, вероятно, обитает группировка линных неразмножающихся птиц, состоявшая в 2016 г. из 164 особей, и группа гнездящихся птиц численностью около 5 пар.

По опросным данным, полученным от людей, часто посещающих р. Усалгин (зал. Николая Охотского моря), взрослые птицы и птенцы этого вида периодически в небольшом количестве встречались в прошлые годы в приустьевой части реки, где распространены вейниковые травостои. В начале июля 2016 г., по опросным сведениям, полученным от двух независимых источников (сотрудники рыббазы артели «Альфа»), в нижнем течении р. Большой Обкан $\left(53.524236^{\circ}\right.$, $138.246349^{\circ}$ ) была встречена группа сухоносов численностью от 40 до 60 особей, две трети которой приходилось на нелетных птенцов размером с крякву.

По опросным сведениям, полученным от рыбаков с. Тугур, в 1980-е гг. сухонос гнездился на перешейке п-ова Тугурский, но позже, вероятно, из-за увеличения антропогенной нагрузки, его размножение там прекратилось.

Черная кряква Anas poecilorhyncha J. R. Forst. внесена в Красную книгу Хабаровского края (2008). В регионе встречи этого вида известны в разных пунктах: от южных районов края до устья р. Амур, Эворон-Чукчагирской низменности и Амурского лимана.

Одиночная черная кряква (вероятно, самец) отмечена нами 17 июля 2016 г. на р. Эльгандё, впадающей в зал. Константина Охотского моря $\left(54.170226^{\circ}, 137.442564^{\circ}\right)$. Птица встречена в стае совместно с тремя самцами кряквы (Anas platyrhynchos).

До настоящего времени формально гнездование черной кряквы в регионе оставалось недоказанным - птенцы и кладки не были найдены (Бабенко, 2000). 6 июля 2016 г. самка черной кряквы с выводком, состоявшим из шести пуховых птенцов примерно 5-дневного возраста, встречена нами в придорожной канаве автотрассы Хабаровск - Комсомольск-на-Амуре вблизи поворота на с. Найхин у западной границы национального парка «Анюйский» $\left(49.260427^{\circ}, 136.484790^{\circ}\right)$. Птиц удалось хорошо рассмотреть с расстояния 5-10 м благодаря тому, что они были обнаружены из автомобиля, который не вызвал у них испуга.

В конце октября 2016 г. потерявшая способность к полету взрослая черная кряква была подобрана местными жителями на территории санатория «Уссури» (окраина с. Бычиха) в 20 км южнее г. Хабаровск. Птица успешно перезимовала в домашнем курятнике совместно с курами и гусями, но способность к полету у нее не восстановилась. Весной 2017 г. она была выпущена на пр. Амурская.

Мандаринка Aix galericulata (L.). Обычный пролетный и гнездящийся вид южных районов Хабаровского края, имеющий в последние годы тенденцию увеличения численности и числа залетов в северные районы региона, внесен в Красную книгу РФ (2001). Ранее наиболее северным пунктом встречи мандаринки в регионе был Тугурский полуостров. В последние годы этот вид неоднократно регистрировали и в самом северном Охотском районе Хабаровского края (Пронкевич, Мороков, 2012).

Весной 2016 г. в бассейне р. Хор нами учтено 105 пар мандаринки. Наиболее высокие плотности птиц зарегистрированы на pp. Хор, Сукпай и Чукен, соответственно $0.33,0.15$ и 0.12 ос. /км русла. Очень низкой численностью мандаринки выделяются водотоки, по берегам которых преобладают вторичные мелколиственные древостои - pp. Кафэ и Катен. Плотность птиц в этих местах составляла, соответственно, 0.03 и 0.09 ос. /км русла.

Плотность мандаринки на обследованном участке р. Анюй увеличивается от верховий водотока к его нижнему течению. В верхнем течении p. Анюй, за пределами национального парка, где река течет в основном одним руслом, мандаринка редка. От верхнего по течению пункта работ до устья р. Богбасу весной 2017 г. были отмечены восемь самцов и одна пара птиц при средней плотности 0.06 пары/км русла реки. Ниже по течению водотока, на территории национального парка средняя плотность птиц на участке от устья р. Богбасу до пр. Нило была 0.3 пары/км русла, от пр. Нило до урочища «Бихан» - 0.4, от урочища «Бихан» до устья р. Манома - 0.9 пары/км русла. Общая численность гнездящихся мандаринок на обследованном участке р. Анюй в пределах ООПТ составляла около 50 пар. С учетом разветвленной сети проток р. Анюй в пределах национального парка общая численность вида, очевидно, может в несколько раз превышать выявленную численность.

В середине июня 2017 г. на 20-километровом участке нижнего течения р. Манома плотность мандаринки составляла 0.4 пары/км русла. В 2017 г. первые птенцы мандаринки в возрасте 1-3 дня отмечены 15 июня.

Чешуйчатый крохаль Mergus squamatus Gould. Фоновый гнездящийся вид крупных горных рек южной части Хабаровского края, внесен в Красную книгу Российской Федерации (2001). К настоящему времени размножение чешуй- 
чатого крохаля в крае достоверно доказано для pp. Хор, Анюй и Кур. Наиболее крупные группировки расположены в бассейнах рр. Анюй и Хор.

В 2016 г. в бассейне р. Хор всего нами учтены 123 пары этого вида. Численность чешуйчатого крохаля на различных участках р. Хор и ее притоках отражает экологическую обстановку, сложившуюся к настоящему времени в обследованном районе.

Наиболее высокие плотности птиц зарегистрированы в нижнем течении р. Чукен, входящей в состав регионального заказника «Чукенский», - 0.71 пары/км русла, на рр. Хор и Сукпай - соответственно 0.28 и 0.26 пары/км русла. Минимальная численность зафиксирована на рр. Кафэ и Катэн - соответственно 0.09 и 0.14 пары/км русла. В долинах этих водотоков распространены вторичные по происхождению древостои.

На р. Анюй протяженностью 393 км в 2010 и 2015 г. проведены учеты чешуйчатого крохаля в нижнем течении русла в пределах национального парка (140 км русла). В середине июня 2010 г. на ООПТ среди 40 учтенных самок 28 были встречены с выводками из 3-5-дневных птенцов. Средняя величина выводка составила 6.1 птенца на одну самку. Кроме того, были отмечены четыре крупных объединенных выводка соответственно из 19, 25, 35 и 70 птенцов. В III декаде мая 2015 г. на том же участке реки учтено 7 пар, 56 самцов, 14 самок и 8 птиц в промежуточном наряде. По-нашему мнению, общая численность чешуйчатого крохаля, размножающегося на p. Анюй в границах национального парка, составляла не менее 50-60 пар (Пронкевич, 2016).

В 2017 г. с конца апреля по конец августа было проведено пять маршрутных учетов чешуйчатого крохаля по р. Анюй в пределах национального парка. За один сплав на постоянном маршруте учитывали от 11 до 76 взрослых чешуйчатых крохалей. Максимальную численность взрослых птиц фиксировали в конце мая. Как в 2017 г., так и в другие годы максимальная плотность чешуйчатого крохаля отмечена на участке от устья р. Богбасу до кордона «Нило» $\left(49.251033^{\circ}, 137.266204^{\circ}\right)$ (в 2017 г. 0.3 пары/км русла). На участке от кордона «Нило» до кордона «Кон» она составляла 0.13 пары/км. На самом нижнем участке маршрута от кордона «Кон» до устья р. Манома чешуйчатый крохаль был отмечен только 1 мая, но, вероятно, то были неразмножавшиеся птицы, так как позднее их там не регистрировали (0.1 пары/км).

В 2017 г. первые птенцы чешуйчатого крохаля появились во второй пятидневке июня. Первый выводок птенцов из 10 пуховичков примерно 5-дневного возраста отмечен 15 июня на участке русла р. Анюй кордон «Нило» - кордон «Кон» $\left(49.257146^{\circ}, 136.699573^{\circ}\right)$. Этот участок водотока освобождается от ледового покрова на дветри недели раньше, чем верхний по течению участок.

По данным мониторинга в 2017 г. отмечено снижение численности птиц по сравнению с 2010 г. Максимально за один сплав в 2017 г. регистрировали до 16 выводков (всего 92 птенца). Средняя величина выводка с птенцами разного возраста составила 5.8 птенца. При проведении учета 21-23 августа 2017 г. 80\% птенцов были летными.

Красавка Anthropoides virgo (L.). Г. Е. Росляков (1989) для территории Хабаровского края приводит красавку в качестве редкого залетного вида. В. Г. Бабенко (2000), В. А. Нечаев и Т. В. Гамова (2009) красавку не упоминают в качестве вида, встречающегося в Хабаровском крае. Документально зарегистрированный залет этого вида с подтверждением фотоснимками отмечен в северной части Хабаровского края в Аяно-Майском районе. Одиночная взрослая птица держалась на побережье Охотского моря с конца июня по конец августа 2016 г. (Андронов, Андронова, 2018).

К нам поступили информация и фотографии технического качества от охотоведа Вяземского района А. Д. Степных, указывающие на встречу красавки на юге края в пос. Шумный $\left(47.277071^{\circ}, 134.983392^{\circ}\right)$. С 28 июня по 3 июля 2018 г. неполовозрелую внешне здоровую птицу ежедневно регистрировали на заброшенном огороде на окраине населенного пункта. Красавка внесена в Красную книгу Российской Федерации (2001) в качестве вида с восстанавливающейся популяцией. Учитывая, что поселок Шумный находится в лесной зоне, где отсутствуют ландшафты, пригодные для размножения вида, данную птицу, несомненно, следует рассматривать как залетную.

Галстучник Charadrius hiaticula L. В Евразии вид распространен от Исландии и Скандинавии к востоку до Берингова моря, к югу до Белоруссии, Польши и Белого моря, северных районов Западной и Восточной Сибири и северного побережья Охотского моря (зал. Шелихова, Тауйская губа, Мотыклейский залив) (Нечаев, Гамова, 2009).

На оконечности галечниковой косы Крюк в зал. Константина Охотского моря (54.062183을 $\left.137.373627^{\circ}\right) 16$ июля 2016 г. мы нашли пару галстучника, проявлявшую беспокойство. На следующий день при помощи бинокля возле взрослых галстучников были обнаружены два пуховых птенца. При попытке наблюдателя приблизиться к ним один из родителей демонстрировал отвлекающее поведение, имитируя 
раненую птицу. Одного птенца отловили для фотографирования и взвешивания (рис. 2, 3), позже его выпустили. Масса птенца составила 6.8 г.

Получено заключение Фаунистической комиссии Рабочей группы по куликам о правильности определения вида. Находка данной пары птиц произошла в 600 км южнее от ранее известных пунктов гнездования галстучника в дальневосточном регионе.

Ходулочник Himantopus himantopus (L.) внесен в Красную книгу РФ (2001) в качестве спорадично распространенного, находящегося на периферии ареала. На территории Хабаровского края его ранее регистрировали вблизи побережья Татарского пролива Японского моря на р. Ботчи и в бух. Силантьева вблизи устья р. Большая Дюанка (Тиунов, 2002; Пронкевич и др., 2016).

В 2016 г. ходулочник был отмечен нами дважды: 15 мая три птицы (пол не установлен) встречены на косе р. Хор вблизи устья р. Катэн $\left(47.51687^{\circ}, 136.08733^{\circ}\right)$ и 21 мая три птицы (самец и две самки) на травяно-моховом болоте у автотрассы Хабаровск - Комсомольск-на-Амуре вблизи места пересечения ею р. Гур (50.036493을 $\left.137.089747^{\circ}\right)$.

Охотский улит Tringa guttifer (Nordm). Этот эндемик Дальнего Востока России занесен в Красный список МСОП в качестве находящегося под угрозой исчезновения. Согласно учету на миграционных остановках мировая численность оценивается в 1000-2000 особей, но систематический учет в гнездовой области и на зимовках не проводился (Bird Life International, 2016). Многие детали биологии вида остаются неизвестными. Единственным орнитологом, которому удалось найти гнезда охотского улита, остается В. А. Нечаев (1991).

При пешем обследовании побережья западной части зал. Константина от устья р. Эльгандё до основания косы Крюк (33 км) 12-13 июля 2016 г. нами учтено 5 особей охотского улита, вероятно, представляющих четыре пары птиц. Координаты мест встречи птиц следующие:

1) пара птиц в приустьевой части р. Эльгандё $\left(54.156816^{\circ}, 137.433885^{\circ}\right)$;

2) одиночная птица вблизи устья р. Гиляк $\left(54.052430^{\circ}\right.$ и $\left.137.298755^{\circ}\right)$;

3) одиночная птица на участке побережья от основания косы Крюк до устья р. Гиляк $\left(54.037860^{\circ}, 137.333190^{\circ}\right)$;

4) одиночная птица на участке побережья от основания косы Крюк до устья р. Гиляк $\left(54.039076^{\circ}, 137.312532^{\circ}\right)$.

Мы предполагаем, что отмеченные птицы находились около птенцов, так как проявляли сильное беспокойство.
Весной 2018 г. в западной части зал. Счастья Охотского моря появление первых охотских улитов, по информации, полученной от охотников с. Власьево (Николаевский район Хабаровско-

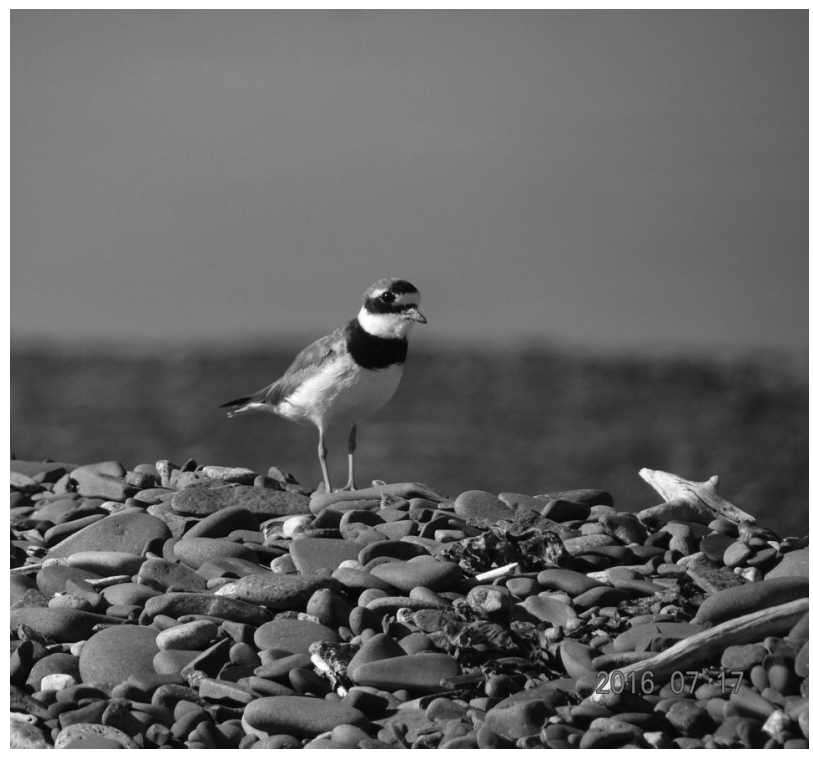

Puс. 2. Галстучник

Fig. 2. Common Ringed Plover

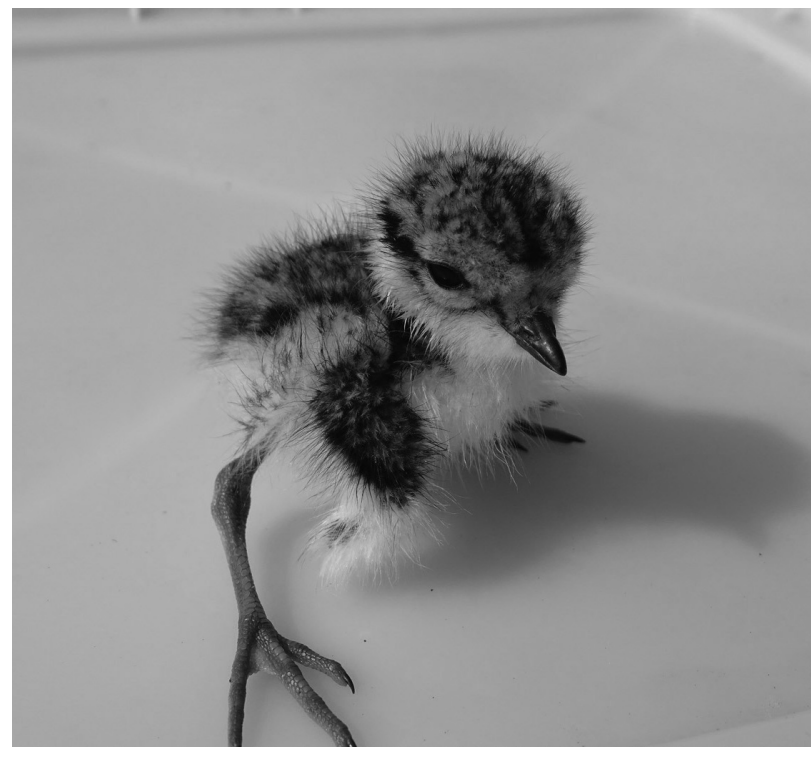

Puc. 3. Пуховой птенец галстучника

Fig. 3. Downy chick of the Common Ringed Plover

го края), было отмечено в четвертой пятидневке мая. Вероятно, охотские улиты прилетают как парами, так и поодиночке. В III декаде мая мы не отмечали групп, состоявших более чем из двух птиц. Сразу же после прилета на места размножения самцы начинают токовать. Токуют как одиночные самцы, так и находящиеся с самкой. Токовые сигналы самцы издают на земле и в воздухе. Чаще их удавалось слышать у птиц, сидев- 
ших на полосе приливно-отливной зоны. Значительно реже - во время брачного полета. Токовые сигналы охотского улита можно передать как «вотэ-рио, вотэ-рио.....». Обычно птицы издают эти звуки всего несколько секунд, но однажды мы слышали серию этих криков непрерывно в течение 5 мин. Кроме того, мы слышали, как самец, пригнувшись над водой, издавал звуки «рио-рио....». Голос беспокоящейся птицы звучит как «вэк-вэк-вэк-вэк». Эти звуки издают взлетающие птицы и птицы, находящиеся возле птенцов. В разных ситуациях меняется их интенсивность.

Самцы охотского улита активно охраняют самку от одиночных самцов своего вида и травников, прогоняя их. В 2018 г. начало обследования охотским улитом гнездопригодной территории отмечено 27 мая. Пара птиц на непродолжительное время садилась на деревья и на нежилое гнездо белоплечего орлана (Haliaeetus pelagicus).

Выход двух пар с птенцами с гнездовых территорий на приморские луга зафиксирован вечером 28 и 29 июня.

Высота травостоя на приморских лугах в месте обитания выводков составляла около $50 \mathrm{~cm}$. Кроме того, эти участки в значительной степени занесены старыми водорослями, под которыми птенцы могли успешно скрываться. Вероятно, поэтому наши попытки найти птенцов в травостое были тщетными.

В первые дни после выхода выводка на приморские луга взрослые птицы подпускали человека на 5-10 м. В это время взрослые птицы соседних пар совместно защищали выводки от

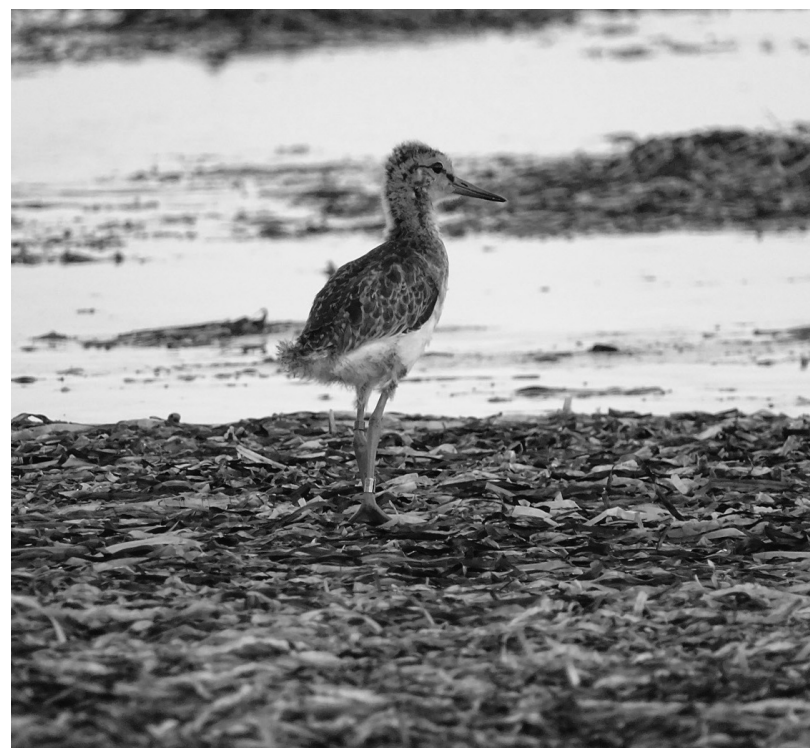

Puc. 4. Птенец охотского улита

Fig. 4. Downy chick of the Nordmann's Greenshank человека. С 1 июля совместная защита выводков прекратилась. Птицы соседних пар почти не реагировали на присутствие человека возле одного из выводков. К этому времени токовые полеты охотского улита полностью прекратились, но брачные голоса самцов иногда можно было слышать у птиц, находившихся на земле возле птенцов.

С 10 июля мы стали наблюдать возле выводков только по одной взрослой птице. Вероятно, у вторых птиц привязанность к птенцам ослабла, и они покинули выводки.

Выход из травостоя на более открытую часть приливно-отливной зоны одного из выводков, состоявшего из трех птенцов примерно 10 15-дневного возраста, был отмечен в бинокль 13 июля. Выход птенцов произошел за 2 ч до темноты. При этом птенцы периодически прятались в зарослях прибрежной травы. Взрослая птица постоянно находилась возле птенцов.

14 июля в 19 ч на приливно-отливной зоне отловили одного пухового птенца. Он быстро убегал от человека, но был отогнан от зарослей травы. Птенца пометили стальным и красным пластиковым кольцами и выпустили (рис. 4).

Всего в 2018 г. нам удалось непродолжительно наблюдать за нелетными птенцами двух пар. У одной пары отмечены три птенца, у другой один. Встреченные птенцы кормились на выброшенных морем водорослях.

В экскрементах взрослого охотского улита, оставленных им 15 июля 2018 г. на искусственном столе, обнаружена не переварившаяся икра рыбы. Размер желтых икринок достигал 2-3 мм (рис. 5).

Японский бекас Gallinago hardwickii (J. Е. Gray). Вид внесен в Красную книгу РФ (2001). Ранее на территории Хабаровского края японского бекаса регистрировали только в самой южной приморской его части - в долине нижнего течения р. Ботчи (Татарский пролив Японского моря) (Тиунов, 2002). Там он был отмечен в качестве обычной птицы в период с 28 мая по 4 июня 2000 г.

Токующий в воздухе и на земле одиночный японский бекас нами был отмечен 2 июня 2018 г. в с. Власьево $\left(53.427445^{\circ}, 140.900180^{\circ}\right)$ (Николаевский район). Характер пребывания птицы выяснить не удалось. Село Власьево расположено в устье р. Иска на западном побережье зал. Счастья Охотского моря и имеет диффузную застройку. Пространство между старыми деревянными строениями занято вейниковыми луговинами, зарослями шиповника, фрагментами березовых и ивняковых древостоев. 


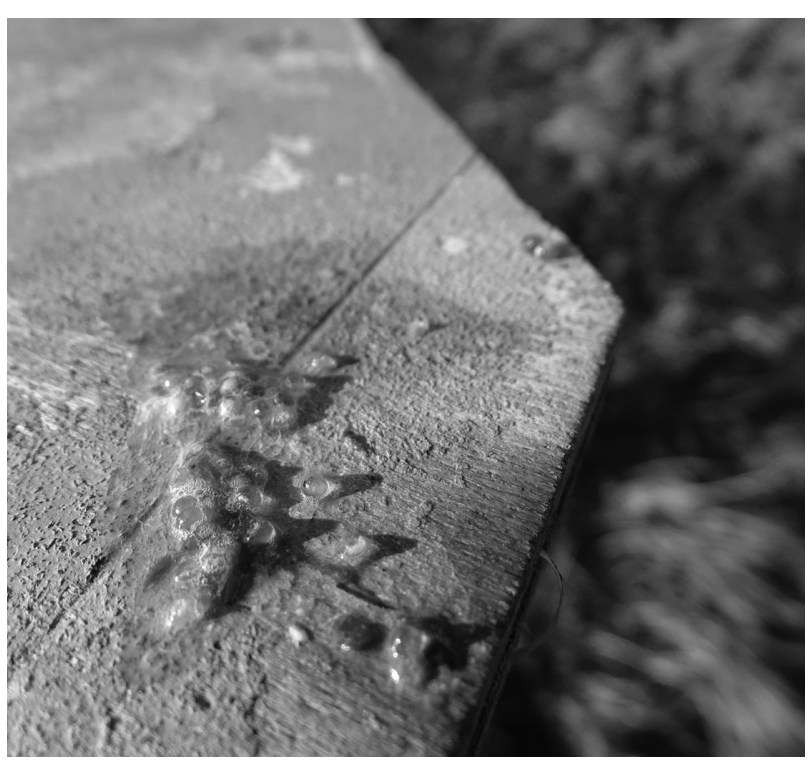

Рис. 5. Не переварившаяся икра рыбы в экскрементах охотского улита

Fig. 5. Indigested fish eggs in the Nordmanns Greenshank excrements

Обыкновенный скворец Sturnus vulgaris L. До настоящего времени статус пребывания обыкновенного скворца на территории Хабаровского края оставался неопределенным (Бабенко, 2000; Пронкевич, 2001; Пронкевич и др., 2011, 2016). С 1986 по 2009 г. одиночных птиц, пары и стаю, в состав которой входили летные молодые, трижды регистрировали в Ульчском, ТугуроЧумиканском и Николаевском районах.

В весенне-летний период 2018 г. обыкновенный скворец встречен нами в качестве обычной птицы в г. Николаевск-на-Амуре и его окрестностях. Одиночных птиц и пары регистрировали 12 июня на территории морского порта и на обочине автодороги к с. Красное. В общей сложности зафиксировано до 20 особей обыкновенного скворца. По сообщению охотоведа М. А. Федосеева, хорошо знающего обыкновенного скворца, в начале мая 2018 г. на территории коопохотпрома «Николаевский» (г. Николаевск-на-Амуре) он видел стаю этих птиц из 30 особей. В середине июля того же года он отметил стаю численностью до 100 особей.

В начале июня 2018 г. с. Богородское, расположенное в Ульчском районе Хабаровского края, с кратковременной экскурсией посетила группа иностранных «бердвотчеров» под руководством C. В. Иванова (бывший сотрудник заповедника «Большехехцирский»). В это время года обыкновенный скворец не представлял там редкости и был встречен в количестве 20 особей.

С 22 мая по 16 июля 2018 г. в западной части зал. Счастья Охотского моря (Николаевский рай- он Хабаровского края) мы периодически отмечали перемещения от 2 до 5 особей обыкновенного скворца. Птицы летали над приморским лугом на участке от основания Петровской косы до с. Власьево. 10 июня того же года в точке с координатами $53.470381^{\circ}$ и $140.913794^{\circ}$ было найдено гнездо обыкновенного скворца. Оно размещалось в природном дупле старой обломанной лиственницы на высоте 10 м на опушке ленточного лиственничного леса, обращенной к морю. Перелеты взрослых птиц от приливно-отливной зоны до гнезда приходилось наблюдать по нескольку раз за день.

В паутинную сеть, установленную на приморском лугу на куликов, 8 июля 2018 г. была случайно отловлена самка обыкновенного скворца второго года жизни, вероятно, из размножавшейся пары с хорошо развитым наседным пятном. У птицы активно линяли второстепенные маховые перья (рис. 6). Масса птицы составляла 77.3 г. Птица помечена на левую лапу стальным кольцом HS012398.

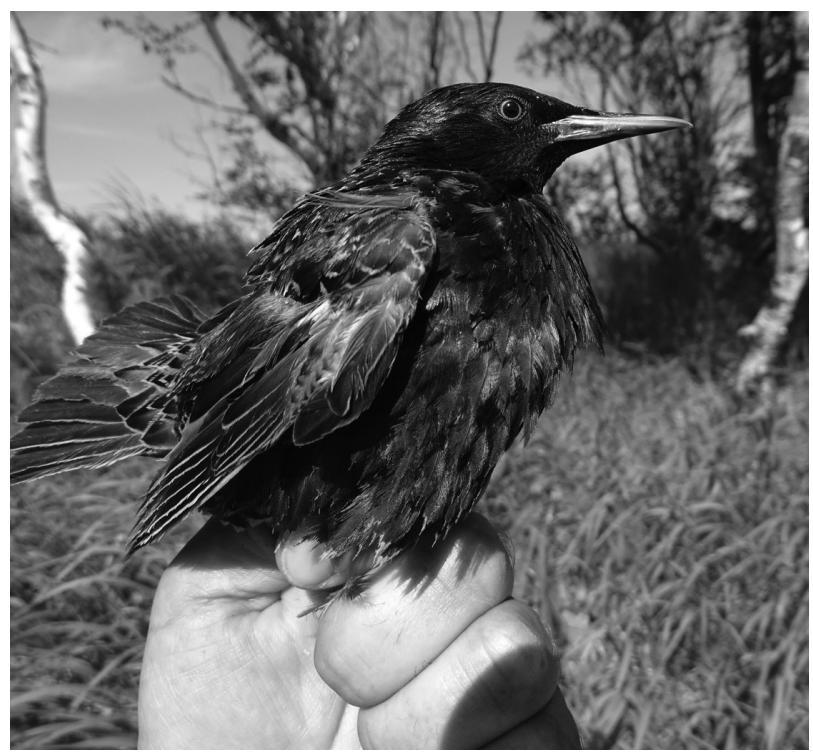

Рис. 6. Самка обыкновенного скворца из зал. Счастья

Fig. 6. Female of the European Starling captured in the Shchastya Bay

\section{ЗАКЛЮЧЕНИЕ}

В 2016-2018 гг. в ходе исследований орнитофауны Хабаровского края получены новые сведения о 12 видах птиц, среди которых 9 занесены в Красную книгу РФ, 1 - в Красную книгу Хабаровского края, 2 вида впервые найдены гнездящимися на территории региона. На наш взгляд, эти сведения заслуживают особого внимания. Часть из них свидетельствует об участившихся 
случаях проникновения в регион новых залетных элементов или новых гнездящихся видов. Другая часть сведений касается состояния численности редких видов или видов, находящихся под угрозой исчезновения.

Регулярные залеты на территорию региона египетской цапли, участившиеся в последние годы, могут быть предвестником смещения границы гнездового ареала вида к северу. Появление этого вида в качестве гнездящегося в первую очередь следует ожидать в южных районах края в пойме р. Уссури, где сравнительно недавно обнаружены гнездящимися сразу два вида цапель - большая белая и кваква (Пронкевич, 2015).

Участившиеся в последние годы встречи мигрирующих колпиц в весенний период и летние встречи в колонии больших бакланов (Phalacrocorax carbo) дают основание предполагать возможное размножение птиц на территории Среднеамурской низменности в Нанайском районе, где участком с повышенной плотностью колониальных птиц (серых цапель (Ardea cinerea) и больших бакланов) являются окрестности о3. Иннокентьевское.

Относительно стабильное состояние численности сухоноса в зал. Ульбанский с 1989 по 2016 г. легко может быть нарушено уже в ближайшие годы возрастающим фактором беспокойства со стороны неорганизованных туристов, поток которых в результате строительства автодороги Хабаровск - зал. Николая и рекламы туров в Западное Приохотье многократно возрос. В этой ситуации одной из мер защиты популяционной группировки сухоноса должна стать организация ООПТ регионального значения «Водноболотное угодье "Морские заливы Николая, Ульбанский и Константина"».

Первый зарегистрированный случай размножения черной кряквы в регионе, вероятно, не случаен, так как еще несколько лет назад мы отмечали тенденцию увеличения численности птиц этого вида в структуре добычи охотников Ульчского, Верхнебуреинского и Хабаровского районов (Пронкевич, 2016). Размножение черной кряквы вблизи обочины оживленной автотрассы свидетельствует о продолжающемся процессе адаптации вида к фактору беспокойства, вызванного хозяйственной деятельностью людей.

Наиболее крупные группировки мандаринки в Хабаровском крае расположены в бассейнах рр. Хор и Анюй. Несмотря на то что долина p. Анюй находится в более суровых климатических условиях по сравнению с долиной р. Хор, линейная плотность вида на р. Анюй значи- тельно превышает таковую на р. Хор. Одним из основным факторов, определяющих это явление, вероятно, выступает заповедный режим национального парка «Анюйский», действующий на значительной площади пригодных для размножения вида местообитаний.

Основной репродуктивный потенциал чешуйчатого крохаля в регионе сосредоточен в бассейнах рр. Хор и Анюй (Пронкевич, 2016). Несмотря на заповедный режим на оптимальном для размножения вида участке р. Анюй, плотности гнездящихся здесь птиц в 2015, 2017 г. оказались такими же, как на р. Хор, где ежегодно ведется весенняя и осенняя охота на водоплавающих птиц Только в 2010 г. на Анюе отмечены более высокие, чем на Хору, плотности размножающихся птиц. Примечательно, что на охраняемом притоке р. Хор - р. Чукен (заказник краевого значения) зарегистрирована самая высокая плотность чешуйчатого крохаля в регионе. Возможно, более благоприятные климатические условия (в частности, сроки схода ледового покрова) в бассейне р. Хор перекрывают положительные качества местообитаний на р. Анюй, имеющих охранный статус.

Участившиеся залеты красавки на территорию Хабаровского края, вероятно, обусловлены положительной тенденцией динамики численности вида в ближайшей части гнездового ареала в Монголии. Мировая численность красавки оценивается в 230-261 тыс. особей (Bird Life International, 2018).

Ближайшим пунктом размножения галстучника к месту нашей находки этого вида в Хабаровском крае является Ямская губа в Магаданской области. Новое место гнездования вида (зал. Константина) отстоит от основного ареала на 1200 км южнее. По мнению П. С. Томковича (письменное сообщение от 06.08.2016 г.), в настоящее время галстучник на Дальнем Востоке расширяет свой ареал и увеличивает численность на Чукотке.

Участок западного побережья зал. Счастья мы обследовали на предмет выяснения численности размножающегося охотского улита в 2009 г. (Пронкевич и др., 2011). Тогда на участке от устья р. Иска до основания Петровской косы было установлено пребывание 7 пар этого вида. В 2018 г. здесь же регулярно фиксировали до 7 пар охотского улита. Это указывает на то, что за последние годы численность гнездящихся птиц не изменилась.

Ранее в гнездовой период место нашей находки японского бекаса (с. Власьево, зал. Счастья) посещал ряд орнитологов (Яхонтов, 1963; Бабенко, 2000; Пронкевич и др., 2011), но вид не 
был отмечен. В случае если мы имеем дело с размножающейся птицей, то ареал японского бекаса за последние десятилетия на материковом побережье мог продвинуться на 600 км к северу.

Возможность размножения обыкновенного скворца в Николаевском районе мы предсказали еще в 2009 г., когда была встречена их стая, при этом взрослые птицы кормили летных птенцов (Пронкевич и др., 2011). Вероятно, к настоящему времени численность обыкновенного скворца значительно выросла - он стал отмечаться не только в г. Николаевск-на-Амуре, но и за его пределами, в том числе в ландшафтах, не связанных с жильем человека и в суровых климатических условиях зал. Счастья.

Автор благодарен В. И. Рослякову, Валерию В. Пронкевичу, Валентину В. Пронкевичу, Д. В. Матвеенко, без которых сбор полевого материала во многом был бы невозможен, А. Д. Степных за информацию о встрече красавки, Р. С. Андроновой за помощь в определении красавки, С. В. Иванову за сообщение о встрече обыкновенного скворца, Ю. Н. Глущенко за определение половой принадлежности обыкновенного скворца, Д. В. Соловьевой за помощь в поиске финансовых средств на выполнение полевых работ и методическую помощь.

Полевые работы выполнены при финансовой поддержке Wildfowl and Wetlands Trust (Слимбридж, Великобритания), РГО (договора № 04/2016-Р и № 10/2018-P), Амурского филиала WWF (договор 642/RU009604-16), Общества сохранения диких животных (WCS) и EAAFP (соглашение от 18.05.2018 г.).

\section{ЛИТЕРАТУРА}

Андронов В. А., Андронова Р. С. Залет красавки на побережье Охотского моря, Россия // Информ. бюл. Рабочей группы по журавлям Евразии. М., 2018. № 14. С. 167-168.

Бабенко В. Г. Птицы Нижнего Приамурья. М. : Прометей, 2000. 725 с.

Воронов Б. А., Поярков Н. Д. К вопросу о ключевых орнитологических территориях в Хабаровском крае // Инвентаризация, мониторинг и охрана ключевых орнитологических территорий России, вып. 2 : Материалы Совещания по программе «Ключевые орнитологические территории России» (1998-2000). М. : Союз охраны птиц России, 2000. С. 16-18.

Воронов Б. А., Пронкевич В. В. О некоторых орнитологических находках в Хабаровском крае // Бюл. МОИП. Отд. биол., 1991. 96 (5). С. 23-28.

Красная книга Российской Федерации (животные) / РАН; гл. редкол. : В. И. Данилов-Данильян и др. М. : АСТ ; Астрель, 2001. 862 с.

Красная книга Хабаровского края : Редкие и находящиеся под угрозой исчезновения виды растений и животных: офиц. изд. / Мин-во природных ресурсов Хабар. края; Ин-т водн. и экол. проблем ДВО РАН.
Хабаровск : Изд. дом «Приамурские ведомости», $2008.631 \mathrm{c}$.

Нечаев В. А. Птицы острова Сахалин. Владивосток : ДВО АН СССР, 1991. 748 с.

Нечаев В. А., Гамова Т. В. Птицы Дальнего Востока России (аннот. каталог). Владивосток : Дальнаука, 2009. $564 \mathrm{c.}$

Пронкевич В. В. Новые сведения о птицах Хабаровского края // Орнитология. 2001. № 29. С. 304-305.

Пронкевич B. В. Результаты учета птиц воднобереговых местообитаний реки Гур (Нижнее Приамурье) в поздневесенний период 2012 года // Амур. зоол. журн. 2013. VI (3). C. 249-252.

Пронкевич В. В. Новые данные о редких представителях орнитофауны Хабаровского края // Вестник СВНЦ ДВО РАН. 2015. № 4. 89-94.

Пронкевич В. В. Современное состояние популяций гусеобразных птиц на территории Хабаровского края // Казарка. 2016. Вып. 19 (1). С. 153-200.

Пронкевич В. В., Мороков В. Е. Заметки о птицах Охотского района Хабаровского края // Амур. зоол. журн. 2012. № 4 (2). С. 194-196.

Пронкевич В. В., Воронов Б. А., Атрохова Т. А. и $\partial p$. Новые данные о редких и малоизученных птицах Хабаровского края // Вестник СВНЦ ДВО РАН. 2011. № 3. С. 70-76.

Пронкевич В. В., Зверев С. В., Мороков В. Е., Ткаченко К. Н. О некоторых орнитологических находках в Хабаровском крае // Рус. орнитол. журн. 2016. Т. 25, № 1240. C. 252-260.

Пронкевич В. В., Росляков В. И., Воронов Б. А. Результаты учета редких и малоизученных птиц в Приамурье и Юго-Западном Приохотье в 2011 году // Амур. зоол. журн. 2011. III (4). С. 381-385.

Розенфельд С. Б., Шиак О. В., Парамонов А. Ю. Встречи сухоноса в районе Ульбанского залива Охотского моря в 2011-2013 гг. // Казарка. 2014. Вып. 17. C. 57-61.

Росляков Г. Е. Краткие сведения о некоторых редких и малоизученных птицах Нижнего Приамурья // Редкие птицы Дальнего Востока. Владивосток : ДВНЦ AH CCCP, 1981. C. 112-115.

Росляков Г. Е. Птицы Хабаровского края : справ. пособие. Хабаровск : ПФ ГО СССР, 1989. 29 с.

Тиунов И. М. Встречи залетных птиц в северной части Среднего Сихотэ-Алиня (юг Хабаровского края) // Рус. орнитол. журн. 2002. № 178. С. 214-215.

Яхонтов В. Д. Новые данные к орнитофауне Нижнего Амура // Вопр. географии Дальнего Востока. Хабаровск : ДВФ СО АН СССР и ПФ ГО СССР, 1963. Сб. 6. С. 215-223.

Bird Life International. 2016. Tringa guttifer. The IUCN red list of threatened species 2016:eT22693225 A93391729.http://dx.doi.org/10.2305/IUCN.UK.2016-3. RLTS.T22693225A93391729.en. (Downloaded on 18 October 2017).

Bird Life International. 2018. Anthropoides virgo. The IUCN red list of threatened species 2018: e. T22692081 A131927771.http://dx.doi.org/10.2305/ IUCN.UK.2018-2.RLTS.T22692081A131927771.en. (Downloaded on 17 December 2018).Acilit praessendip 


\title{
NEW DATA ON RARE BIRDS OF KHABAROVSK KRAI
}

\author{
V. V. Pronkevich ${ }^{1,2}$ \\ ${ }^{1}$ Institute of Water and Ecological Problems, FEB RAS, ${ }^{2}$ Zapovednoye Priamuriye FSBI, Khabarovsk
}

\begin{abstract}
The paper is based on the author's observations made in Khabarovsk Krai in 2016-2018. For the first time in the area, reproduction of the European Starling and Common Ringed Plover was recorded. Breeding of the Swan Goose in the Ulbansky Bay, the Sea of Okhotsk, was documented. New records of the vagrant Cattle Egret and Eurasian Spoonbill in the region are reported. New data on abundance of the Mandarin Duck and Scaly-sided Merganser on the Khor and Anyui rivers as well as some details of biology of the globally endangered species, the Nordmann's Greenshank in the Bay of Schast'e of the Sea of Okhotsk are presented.
\end{abstract}

Keywords: distribution, abundance, rare bird species, Khabarovsk Krai.

\section{REFERENCES}

Andronov, V. A.; Andronova, R. S., 2018, The Vagrant Demoiselle Crane on the Sea of Okhotsk Coast, Russia, Newsletter of Crane Working Group of Eurasian, 14, 167-168 [In Russian].

Babenko, V. G., 2000, Birds of the Lower Amur Region, Moscow, Prometheus [In Russian].

Bird Life International, 2016, Tringa guttifer, The IUCN Red List of Threatened Species 2016: eT22693225A93391729,http://dx.doi.org/10.2305/ IUCN.UK.2016-3.RLTS.T22693225A93391729.en. (Downloaded on 18 October 2017).

Bird Life International, 2018, Anthropoides virgo. The IUCN Red List of Threatened Species 2018: e.T22692081A131927771,http://dx.doi.org/10.2305/ IUCN.UK.2018-2.RLTS.T22692081A131927771. en. (Downloaded on 17 December 2018).

Nechaev, V.A., 1991, Birds of Sakhalin Island, Vladivostok, DVO AN SSSR [In Russian].

Nechaev, V. A.; Gamova, T. V., 2009, Birds of the Russian Far East (Annotated Catalogue), Vladivostok, Dalnauka [In Russian].

Pronkevich, $V . V ., 2001$, New Data on Birds of the Khabarovsk Krai, Ornithology, 29, 304-305 [In Russian].

Pronkevich, V. V., 2013, Results of Accounting Birds of Water-Coastal Habitats of the Gur River (Lower Amur Region) in the Late Spring Period of 2012, Amur Zoological Journal, VI, 3, 249-252 [In Russian].

Pronkevich, V. V., 2015, New Data on Rare Representatives of the Khabarovsk Krai Avifauna, Bulletin of the North-East Science Center, 4, 89-94 [In Russian].

Pronkevich, V. V., 2016, Present Status of the Goose Birds Populations in Khabarovsk Krai, Cazarca, 19, 1, 153-200 [In Russian].

Pronkevich, V. V.; Morokov, V.E., 2012, Notes on the Birds of the Okhotsk District of Khabarovsk Krai, Amur Zoological Journal, 4, 2, 194-196 [In Russian].

Pronkevich, V. V.; Roslyakov, V. I.; Voronov, B. A., 2011, Results of Accounting Rare and Poorly Studied Birds in the Amur Region and South-West Priokhotye in 2011, Ibid., III, 4, 381-385 [In Russian].
Pronkevich, V. V.; Voronov B. A.; Atrokhova T. A.; Antonov A. L.; Adnagulov E. V.; Oleinikov A. Yu., 2011, New Data on Rare and Poorly Studied Birds of Khabarovsky Kray, Bulletin of the North-East Science Center, 3, 70-76 [In Russian].

Pronkevich, V. V.; Zverev S. V.; Morokov V. E.; Tkachenko K. N., 2016, About Some Ornithological Findings in Khabarovsk Krai, Russian Journal of Ornitology, 25, 1240, 252-260 [In Russian].

Red Book of Khabarovsk Krai: Rare and Endangered Species of Plants and Animals, 2008, Khabarovsk, Amurskiye Vedomosti [In Russian].

Red Book of the Russian Federation (Animals), 2001, Moscow, Astrel [In Russian].

Rosenfeld, S. B.; Shpak, O. V.; Paramonov A. Yu., 2014, Sighting of the Swan Goose in the Ulansky Bay Area of the Sea of Okhotsk in 2011-2013, Cazarca, 17, 57-61 [In Russian].

Roslyakov, G. E., 1981, Brief Information on Some Rare and Poorly Studied Birds of the Lower Amur Region, Rare Birds of the Far East, Vladivostok, DVNC AN SSSR, 112-115 [In Russian].

Roslyakov, G. E., 1989, Birds of Khabarovsk Krai, Reference Book, Khabarovsk, Amur Branch of the Geographical Society of the SSSR [In Russian].

Tiunov, I. M., 2002, Sighting of Vagrant Birds in the Northern Part of the Middle Sikhote-Alin' (South of Khabarovsk Krai), Russian Journal of Ornitology, 178, 214-215 [In Russian].

Voronov, B. A.; Poyarkov, N. D., 2000, On the Issue of Key Ornithological Territories in Khabarovsk Krai, Inventory, Monitoring, and Protection of Key Ornithological Territories of Russia, Iss. 2, Materials of the Meeting on the Program Key Ornithological Territories of Russia (1998-2000), Moscow, Soyuz Okhrany Ptits Rossiyi, 16-18 [In Russian].

Voronov, B. A.; Pronkevich V. V., 1991, On Some Ornithological Findings in the Khabarovsk Krai, Bull. of MSN, Biol., 96, 5, 23-28 [In Russian].

Yakhontov, V. D., 1963, New Data for the Avifauna of the Lower Amur, Voprosy Geografiyi Dalnego Vostoka, Khabarovsk, 6, 215-223 [In Russian]. 